\title{
Sistem Informasi Geografis Persebaran Titik Api di Indonesia Menggunakan OpenGeo Suite 3.0
}

\author{
Geographic Information System for Hotspots Distribution in \\ Indonesia using OpenGeo Suite 3.0
}

SONITA VERONICA BR BARUS, IMAS SUKAESIH SITANGGANG*

\begin{abstract}
Abstrak
Kebakaran hutan merupakan masalah yang serius karena dapat mengakibatkan dampak buruk terhadap lingkungan. Salah satu upaya pencegahan kebakaran hutan adalah membangun sistem informasi geografis (SIG) berbasis web untuk mengelola data histori titik api sebagai indikator terjadinya kebakaran. Penelitian ini bertujuan untuk membangun SIG berbasis web menggunakan perangkat lunak OpenGeo Suite 3.0. OpenGeo Suite merupakan aplikasi yang mengemas sistem manajemen basis data PostgreSQL dengan ekstensi spasial PostGIS dan server peta Geoserver sehingga memberikan kemudahan dalam pembangunan dan pengelolaan SIG berbasis web. SIG yang dibangun menyediakan fitur utama yaitu menampilkan peta Indonesia, fungsi pan map, zoom in, zoom out, dan fungsi pencarian persebaran titik api berdasarkan wilayah dan waktu. Dengan adanya SIG berbasis web ini, pengelolaan data histori titik api dapat dilakukan dengan mudah sehingga dapat membantu pengguna dalam penyediaan data histori dan persebaran titik api untuk wilayah Indonesia.
\end{abstract}

Kata Kunci: OpenGeo Suite, sistem informasi geografis berbasis web, titik api.

\begin{abstract}
Forest fire is a serious problem that causes negative impacts to environment. One of activities to prevent forest fires is to develop a web-based geographic information system (GIS) to manage historical hotspot data as an indicator of fires. In this research, a web based GIS was developed using OpenGeo Suite software. OpenGeo Suite is an application which bundles PostgreSQL database management with the spatial extension PostGIS and Geoserver map server so that the web-based GIS is easy to develop and to manage. The GIS which was developed provides main features that are displaying map of Indonesia, pan map function, zoom in, zoom out, and searching functions for hotspots distribution based on region and time. Using the web based GIS, historical hotspot data can be easily managed in order to assist users in providing summaries of historical hotspot data and its distribution in Indonesia.
\end{abstract}

Keywords: hotspot, OpenGeo Suite, web-based geographic information system.

\section{PENDAHULUAN}

Kebakaran hutan merupakan masalah yang serius karena dapat menimbulkan dampak buruk terhadap lingkungan seperti berdampak pada ekosistem, mengakibatkan kerugian secara ekonomi, kerusakan harta benda, mengganggu kesehatan masyarakat dan dampak yang paling mengancam saat ini adalah global warming. Oleh karena itu, pengendalian kebakaran hutan yang baik sangat diperlukan. Salah satu upaya pencegahan kebakaran hutan adalah dengan membangun sebuah sistem informasi geografis (SIG) untuk mengelola data histori titik api yang merupakan indikator terjadinya kebakaran. Sistem informasi geografi adalah sebuah sistem komputer yang dapat menangkap, menyimpan, melakukan query, menganalisis, dan menampilkan data geografi (Chang 2002). 
SIG telah banyak dibangun untuk mengolah data kebakaran hutan. Studi oleh Mulyanto et al. (2001) membangun SIG yang diintegrasikan dengan teknologi penginderaan jarak jauh untuk menganalisis data kebakaran hutan di Kalimantan Timur. Dalam penelitian lainnya, SIG untuk pemodelan resiko kebakaran hutan di lahan gambut berbasis pendekatan Analytical Hierarchy Process (AHP) telah dibangun untuk wilayah Pekan, Pahang Malaysia (Setiawan et al. 2004). Pemodelan dalam SIG ini berdasarkan lima parameter yaitu tipe bahan bakar, jalan, ketinggian, kemiringan dan aspek yang mempengaruhi kemunculan dan persebaran kebakaran hutan. Model resiko kebakaran hutan berbasis SIG dan penginderaan jarak jauh juga telah dihasilkan oleh Hai-wei et al. (2004) untuk menentukan area hutan yang beresiko terbakar di pegunungan Da Hinggan, China. Peta zona resiko kebakaran yang dihasilkan dalam penelitian tersebut dapat digunakan sebagai panduan dalam pengelolaan kebakaran hutan dan sebagai dasar dalam penentuan strategi pencegahan kebakaran hutan (Hai-wei et al. 2004). Penelitian lain oleh Dong et al. (2006) telah membangun SIG untuk mengklasifikasikan faktor-faktor lingkungan yang berpotensi mempengaruhi terjadinya kebakaran hutan di Provinsi Jilin, China. SIG tersebut menghasilkan tiga peta yaitu peta resiko kebakaran berbasis bahan bakar, peta resiko kebakaran berbasis topografi, dan peta resiko kebakaran berbasis faktor anthropogenic (Dong et al. 2006). Di samping itu, SIG juga telah dikembangkan untuk pemetaan tingkat resiko kebakaran gambut di wilayah Penor/Kuantan District, Pahang, Malaysia, dengan melibatkan tipe bahan bakar, jalan dan kanal (Razali et al. 2010).

Pengembangan aplikasi SIG sekarang ini mengarah pada aplikasi berbasis web yang dikenal dengan WebGis karena pengembangan di lingkungan jaringan menunjukkan potensi yang besar dalam memberikan informasi geografis. Sebagai contoh adanya peta online memungkinkan pengguna dapat dengan mudah mendapatkan informasi tanpa mengenal batas geografi penggunanya.

Pada penelitian ini dibangun WebGis untuk pengelola data histori titik api di Indonesia menggunakan OpenGeo Suite 3.0. Sistem informasi tersebut dilengkapi dengan modul pencarian persebaran titik api berdasarkan lokasi dalam rentang waktu tertentu dan hasil pencariannya berupa peta, tabel dan grafik sehingga diharapkan perubahan jumlah dan distribusi titik api dapat terlihat lebih jelas. Hasil penelitian ini diharapkan dapat bermanfaat bagi pihak-pihak yang memerlukan informasi berupa ringkasan data histori titik api dalam pencegahan kebakaran hutan sehingga dapat membantu dalam pengambilan keputusan terkait kebakaran hutan.

\section{METODE}

\section{Data dan Sumber Data}

Data yang yang dipakai dalam penelitian diperoleh dari www.inigis.org, Departemen Kehutanan Republik Indonesia (DKRI), dan NASA. Data yang diperoleh dari www.inigis.org adalah peta Indonesia dengan format shapefile, data yang diperoleh dari DKRI adalah data hotspot 2002-2005 dengan format .txt, dan data yang diperoleh dari NASA adalah data hotspot 2006-2012 dengan format .csv. Area studi penelitian ini adalah wilayah Indonesia. Indonesia merupakan negara kepulauan dengan luas wilayah \pm 5.2 juta $\mathrm{km}^{2}$, luas wilayah daratan berkisar 1.9 juta $\mathrm{km}^{2}$ dan luas daerah laut berkisar 3.3 juta $\mathrm{km}^{2}$ (Sugiharyanto 2007).

\section{Lingkungan Pengembangan}

Perangkat keras yang digunakan dalam penelitian ini berupa komputer personal dengan spesifikasi Prosesor Intel Core i3-3217U, RAM 4 GB, dan Harddisk 500 GB. Adapun perangkat lunak yang digunakan adalah Sistem Operasi Windows 8 Professional, OpenGeo Suite 3.0 yang merupakan aplikasi yang mengemas sistem manajemen basis data PostgreSQL dengan ekstensi spasial PostGIS dan server peta Geoserver, Apache 2.2.14 sebagai web 
server, Adobe Dreamweaver CS5.5 sebagai kode editor, dan Quantum GIS 1.8.0 untuk pengolahan data spasial.

Perangkat lunak utama yang digunakan dalam penelitian ini adalah OpenGeo Suite. OpenGeo Suite merupakan perangkat lunak geospasial berupa tumpukan (stack). Dikatakan demikian karena beberapa komponen diletakkan di atas komponen lainnya. Komponen yang sifatnya penting diletakkan di bawah sedangkan komponen yang sifatnya pendukung diletakkan di atasnya (OpenGeo 2012). Arsitektur OpenGeo Suite dapat dilihat pada Gambar 1. Arsitektur OpenGeo Suite terdiri atas tiga lapisan utama yaitu (OpenGeo 2012):

a. Database. OpenGeo Suite menggunakan PostgreSQL sebagai sistem manajemen basis data dan PostGIS. PostGIS merupakan ekstensi PostgreSQL yang menawarkan kemampuan untuk mengelola data spasial.

b. Application Server. Pada lapisan ini terdapat dua komponen yaitu GeoServer dan GeoWebCache. GeoServer adalah perangkat lunak server berbasis Java yang memungkinkan pengguna untuk melihat dan mengedit data geospasial. GeoWebCache digunakan untuk meningkatkan kinerja sistem yang dibangun.

c. User Interface. User Interface OpenGeo menggunakan GeoExplorer. GeoExplorer adalah antarmuka berbasis browser untuk menyusun dan mempublikasikan aplikasi pemetaan peta.

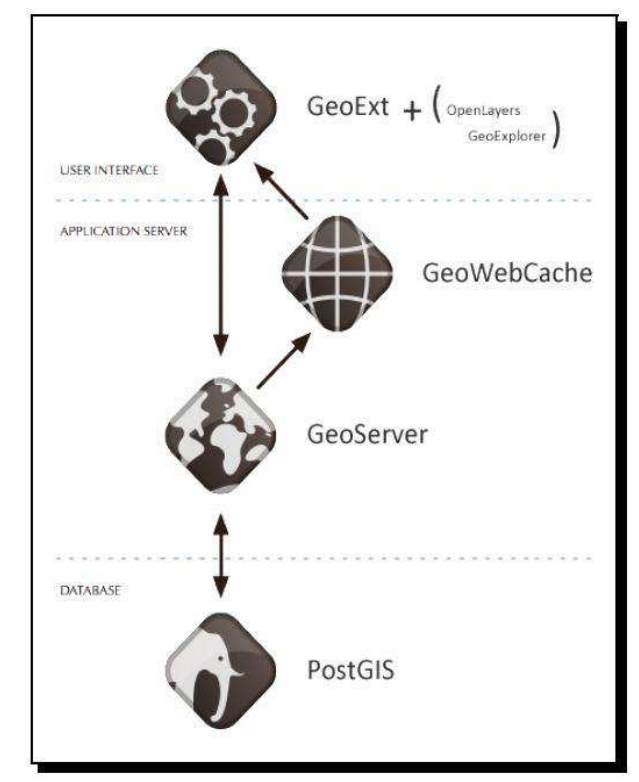

Gambar 1 Arsitektur OpenGeo Suite (OpenGeo 2012)

Pembangunan SIG dilakukan mengikuti tahapan-tahapan dalam metode linear sequential model yang mencakup tahapan analisis, perancangan, implementasi dan pengujian. Tahapan-tahapan ini diadopsi dari metode Waterfall (Pressman 2005). Analisis yang akan dilakukan adalah analisis terhadap kebutuhan SIG berbasis web yaitu kebutuhan fungsional SIG berbasis web, dan kebutuhan antarmuka sistem. Proses desain menerjemahkan syarat kebutuhan ke sebuah perancangan sistem yang dapat diperkirakan sebelum melakukan tahapan implementasi. Desain yang dilakukan adalah desain proses sistem dalam bentuk diagram konteks, perancangan basis data dalam bentuk diagram keterhubungan antartabel dan perancangan antarmuka sistem. Perancangan basis data untuk SIG dilakukan melalui tiga tahapan yaitu perancangan konseptual, perancangan logik dan perancangan fisik.

Sistem yang telah dirancang pada tahap desain akan direalisasikan pada tahap implementasi. Pada tahap implementasi dilakukan pembuatan basis data, pembuatan server peta, dan pembuatan antarmuka. Pengujian sistem dilakukan menggunakan metode Blackbox. Pengujian ini dengan memberikan masukan tertentu apakah keluaran yang dihasilkan sesuai dengan yang diinginkan. 


\section{HASIL DAN PEMBAHASAN}

\section{Analisis}

SIG histori persebaran titik api di Indonesia adalah suatu sistem informasi geografis berbasis web yang menyajikan pemetaan persebaran titik api di Indonesia yang dilengkapi dengan kemampuan pencarian titik api berdasarkan rentang waktu tertentu. Informasi tersebut diharapkan dapat digunakan dalam menganalisis data titik api sebagai pendeteksian dini kebakaran hutan serta rencana penanggulangannya. Secara umum fungsi-fungsi yang ada di dalam sistem adalah

1 Menampilkan peta Indonesia

2 Menyediakan fungsi pan map (fungsi untuk menggeser peta sesuai dengan keinginan), zoom in, zoom out

3 Menampilkan hasil pencarian titik api berdasarkan lokasi dalam rentang waktu tertentu.

Data yang didapat dari Departemen Kehutanan Republik Indonesia (DKRI) dan NASA dipraproses terlebih dahulu. Praproses yang dilakukan meliputi seleksi atribut dan pembersihan data. Pada tahap seleksi atribut, ditentukan atribut yang relevan untuk pembangunan SIG. Atribut tersebut adalah tahun, bulan, tanggal, lintang, dan bujur. Atribut waktu dan NOAA dari DKRI dan atribut brightnees, scan, track, acq_time, satellite, confidence, version, bright_t31,frp dari NASA tidak digunakan karena dianggap tidak diperlukan dalam penelitian ini. Atribut provinsi dan kabupaten dari DKRI tidak digunakan karena mengandung banyak nilai kosong (null). Data provinsi dan kabupaten di Indonesia diperoleh dari peta digital (dengan format shp). Pada tahap pembersihan data, diidentifikasi terdapat 2 field yang mempunyai bulan ke-18, sehingga data tersebut dibuang karena bulan hanya sampai bulan ke-12. Jumlah titik api dari tahun 2002 sampai 2012 dapat dilihat pada Tabel 1.

Tabel 1 Jumlah titik api dari tahun 2002 sampai 2012

\begin{tabular}{ccc}
\hline \multirow{2}{*}{ Tahun } & \multicolumn{2}{c}{ Jumlah } \\
\cline { 2 - 3 } & Sebelum praproses & Sesudah praproses \\
\hline 2002 & 91.322 & 81.692 \\
2003 & 155.875 & 88.370 \\
2004 & 89.916 & 79.442 \\
2005 & 47.400 & 39.767 \\
2006 & 223.285 & 116.777 \\
2007 & 97.673 & 31.467 \\
2008 & 97.614 & 28.704 \\
2009 & 171.019 & 75.011 \\
2010 & 63.281 & 15.762 \\
2011 & 132.727 & 45.831 \\
2012 & 161.370 & 52.104 \\
\hline
\end{tabular}

\section{Perancangan}

Pada tahapan ini dilakukan perancangan basis data dan antarmuka sistem berdasarkan aliran data dan kontrol, proses fungsional, dan informasi yang terkandung di dalam sistem dalam SIG. Secara umum proses fungsional yang ada dalam sistem adalah menampilkan peta dan hasil pencarian data persebaran titik api berdasarkan kriteria pencarian yang diinputkan oleh pengguna. Pengguna dapat menggunakan fungsi-fungsi peta untuk menganalisis lebih lanjut hasil pencarian yang ditampilkan dalam bentuk peta.

Perancangan basis data meliputi perancangan konseptual, perancangan logik dan perancangan fisik. Pada tahap konseptual dilakukan identifikasi data yang dibutuhkan dan penyajian model data. Data yang dibutuhkan adalah data spasial dan data atribut. Tipe data vektor yang digunakan dalam SIG persebaran titik api di Indonesia yaitu poligon untuk peta Indonesia, dan titik untuk titik api. Data atribut yang digunakan adalah data kabupaten yang 
terdiri dari kode kabupaten (kode_kab), nama kabupaten, dan nama provinsi. Perancangan logik basis data ditampilkan dalam diagram keterhubungan antartabel yang dapat dilihat pada Gambar 2. Basis data dirancang sesuai dengan kebutuhan sistem (Tabel 2). Selanjutnya perancangan fisik dilakukan dengan menentukan tipe data dari tiap data atribut dan menyimpan data dalam bentuk yang dapat dengan mudah digunakan dalam sistem. Oleh karena itu data spasial disimpan dalam shapefile dalam DBMS PostgreSQL dengan ekstensi spasial PostGIS.

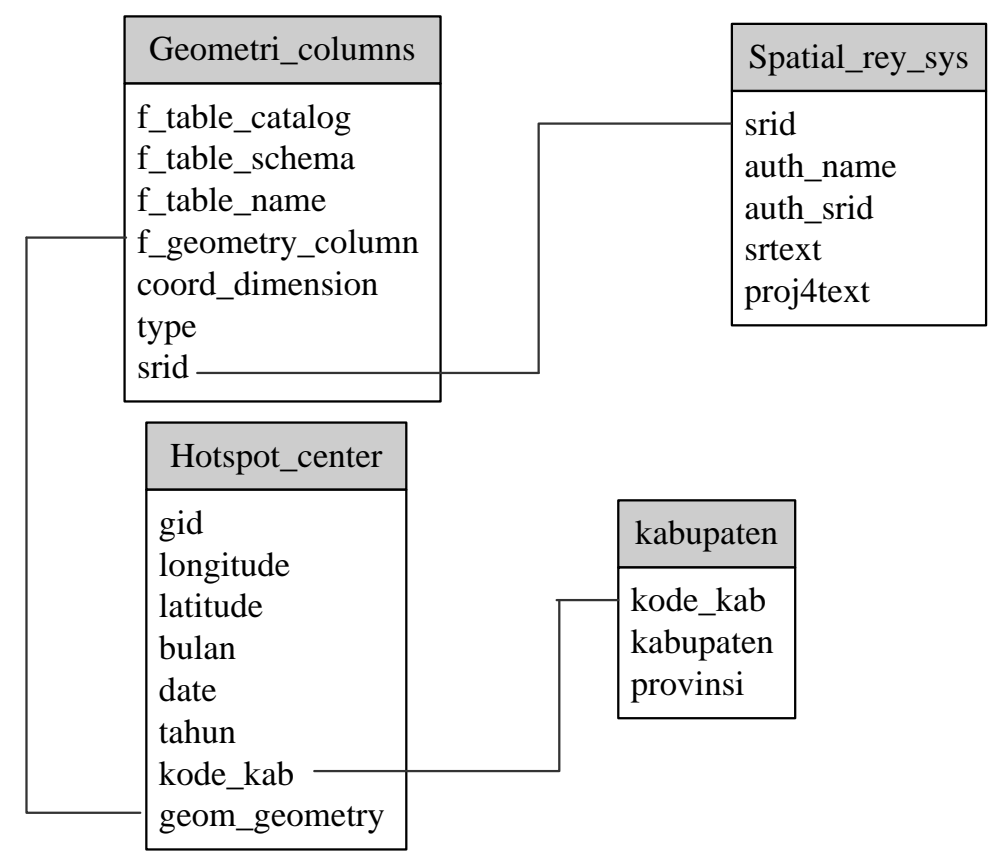

Gambar 2 Diagram keterhubungan antartabel

Tabel 2 Tabel-tabel dalam basis data persebaran titik api di Indonesia

\begin{tabular}{ll}
\hline \multicolumn{1}{c}{ Nama Tabel } & \multicolumn{1}{c}{ Kegunaan } \\
\hline Hotspot_center & Memberikan informasi mengenai lokasi hotspot \\
Kabupaten & Memberikan informasi mengenai nama kabupaten \\
Indo_districts & $\begin{array}{l}\text { Memberikan informasi mengenai lokasi indonesia seperti } \\
\text { kabupaten dan provinsi. }\end{array}$ \\
spatial_ref_sys & Referensi spasial dari kolom geometri \\
geometry_columns & Identifikasi tabel yang memiliki atribut spasial \\
\hline
\end{tabular}

Di samping perancangan basis data, pada tahap ini dilakukan perancangan antarmuka sistem. Antarmuka sistem terdiri dari fungsi peta dan modul pencarian dan hasil pencarian. Fungsi peta yang dibuat adalah pan map, zoom in, zoom out. Modul pencarian terdiri dari tiga kategori yaitu pencarian berdasarkan waktu, berdasarkan lokasi dan berdasarkan waktu dan lokasi. Hasil pencarian berupa, tabel, grafik dan pemetaan titik api ke peta.

\section{Implementasi}

SIG ini dibangun menggunakan perangkat lunak OpenGeo Suite pada platform Windows. Perangkat lunak DBMS yang digunakan adalah PostgreSQL yang sudah tersedia pada saat OpenGeo Suite diinstal. Implementasi yang dilakukan pada tahap ini adalah implementasi basis data, implementasi server peta, dan implementasi antarmuka.

Dalam implementasi basis data, data titik api yang telah diperoleh dalam format txt dikonversi terlebih dahulu ke format shapefile. Proses konversi dilakukan dengan tool Quantum GIS. Data yang telah dikonversi dalam bentuk shapefile di import ke dalam PostGIS. PostGIS memiliki kemampuan untuk mengelola data spasial. Import data ke PostGIS menggunakan OpenGeo Suite dilakukan dengan memilih import shapefile yang 
terdapat pada dashboard OpenGeo. Error dapat terjadi dikarenakan perbedaan port. Port yang digunakan OpenGeo PostGIS adalah 54321 bukan nilai port default PostgreSQL (OpenGeo 2012).

Sistem dikembangkan dengan menggunakan arsitektur client-server. Penggunaan arsitektur ini telah mencukupi kebutuhan fungsional sistem karena aplikasi yang dikembangkan berbasis web sederhana. Arsitektur client-server setidaknya memiliki user interface pada sisi client dan data terdistribusi yang disimpan pada sisi server. Client mengirimkan request melalui antarmuka aplikasi (web browser) ke sebuah web server. Web server menerima request pengguna dan mengirimkannya melalui Uniform Resources Locator (URL). HTTP membangkitkan koneksi antara client dan server. Dalam sistem ini request peta yang dikirimkan pengguna melalui web browser akan diterima terlebih dahulu oleh Web Server. Kemudian web server akan meneruskannya untuk diproses oleh bahasa pemrograman PHP yang menerima paramater melalui URL. Paramater yang diterima oleh web server akan dilanjutkan kepada Geoserver yang menjadi server data geospasial. Arsitektur yang digunakan dalam pengembangan sistem dapat dilihat pada Gambar 3.

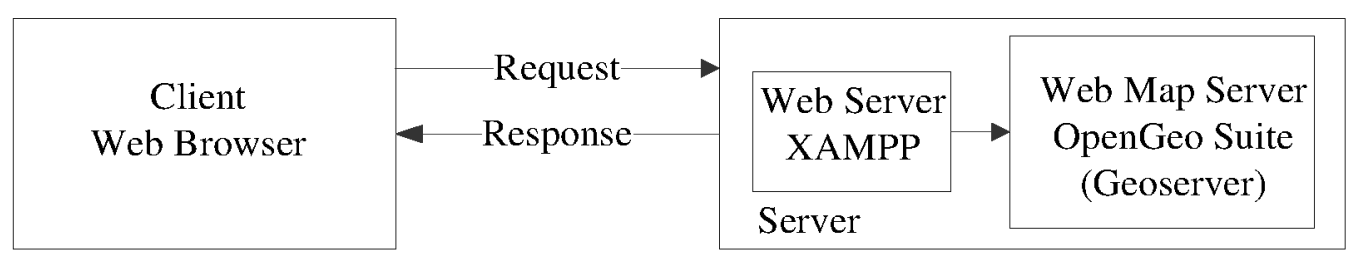

Gambar 3 Arsitektur sistem dengan client-server

Tahapan pembuatan layer pada Geoserver adalah sebagai berikut

1. Membuat workspace

Workspace merupakan ruang kerja yang menampung layer-layer yang akan dibuat. Workspace dirancang untuk menjadi ruang terpisah, terisolasi yang berhubungan dengan suatu proyek tertentu. Hal tersebut memungkinkan untuk menggunakan layer dengan nama yang identik tanpa konflik. Nama workspace yang telah dibuat pada penelitan ini adalah hotspotIndo.

2. Membuat store

Store merupakan ruang konfigurasi untuk mengatur penyimpanan data yang tersedia ke dalam GeoServer. Terdapat pilihan berdasarkan jenis data yaitu data vektor dan data raster. Data dimasukkan ke dalam GeoServer melalui konfigurasi PostGIS yang telah dibuat sebelumnya. Pada saat store berhasil dibuat maka akan muncul layer-layer dari sumber data yang telah dipilih sebelumnya dan terdapat pilihan layer apakah layer tersebut dipublikasi atau tidak. Apabila layer yang tersedia dipublikasikan maka Geoserver akan menampilkan halaman konfigurasi untuk melengkapi informasi yang dibutuhkan setiap layer. Informasi tersebut meliputi nama layer, pemilihan nilai sistem koordinat referensi, bounding box yang dibangkitkan dari data (Gambar 4).

3. Import data ke Geoserver

Format data dapat berupa file spasial (shapefile, GeoTIFF, ArcGrid, JPEG2000, GDAL formats), import dari PostGIS, Oracle, SQL Server. Pada penelitian ini data diambil dari PostgreSQL dengan memilih workspace yang telah dibuat.

4. Melihat hasil peta

Untuk melihat peta sesuai layer yang telah dibuat, pengguna dapat mengakses layer preview. Dalam menu view pada layer preview terdapat tiga kategori pilihan yaitu berdasarkan aplikasi (Open Layers, Google Earth, dan GeoExplorer), format WMS (KMZ, TIFF, JPEG, PNG, PDF, KML, GIF dan lain-lain), dan format WFS (application/gml+xml: version 3.2, CSV, GeoJSON, GML2, GML3, dan shapefile). GeoExplorer menjadi bagian dari OpenGeo pada lapisan user interface. GeoExplorer 
adalah sebuah aplikasi web berdasarkan kerangka GeoExt yang digunakan untuk menyusun dan menerbitkan peta.

GeoExplorer adalah sebuah aplikasi web untuk menyusun dan menampilkan peta. Dengan GeoExplorer, pengguna dapat dengan cepat membuat peta dari GeoServer. GeoExplorer menyediakan menu publish map untuk peta yang telah dibuat dengan menyediakan link untuk mengakses peta dari halaman web. GeoExplorer memiliki fitur yang baik tetapi penggunaan GeoExplorer untuk menyajikan SIG sesuai dengan ruang lingkup yang diinginkan belum ditemukan yaitu untuk menyajikan hasil pencarian persebaran titik api dalam bentuk peta, grafik, dan tabel berdasarkan lokasi dalam rentang waktu tertentu. Sehingga untuk implementasi antarmuka yang digunakan adalah Open Layers. Kode program Open Layers didapat dari klik kanan pada layer yang ada pada GeoServer. Untuk memetakan titik api ke dalam peta digunakan fungsi tambahan yaitu fungsi pencarian dan fungsi get_markers.

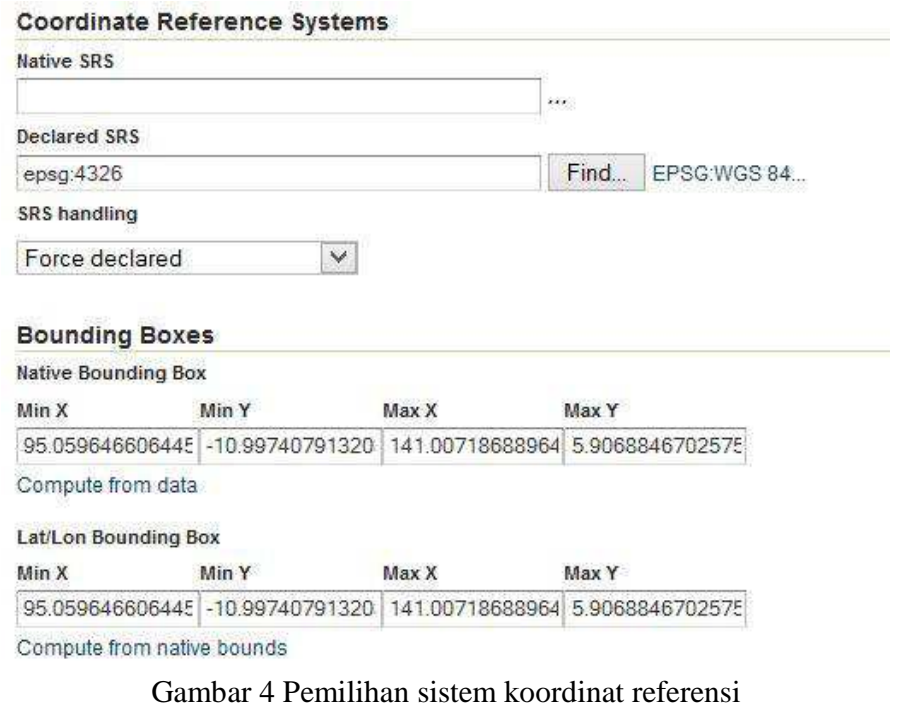

Pencarian titik api dapat dilakukan berdasarkan waktu dan lokasi. Hasil pencarian titik api ditampilkan dalam bentuk tabel, peta dan grafik. Antarmuka yang menyajikan hasil pencarian titik api berdasarkan waktu dapat dilihat pada Gambar 5. Pada antarmuka tersebut terdapat peta yang menunjukkan persebaran titik api (bagian (a) pada Gambar 5), area untuk memasukkan kata kunci (bagian (b) pada Gambar 5) dan hasil pencarian dalam bentuk tabel (bagian (c) pada Gambar 5). Grafik hasil pencarian titik api berdasarkan waktu dapat dilihat pada Gambar 6. 

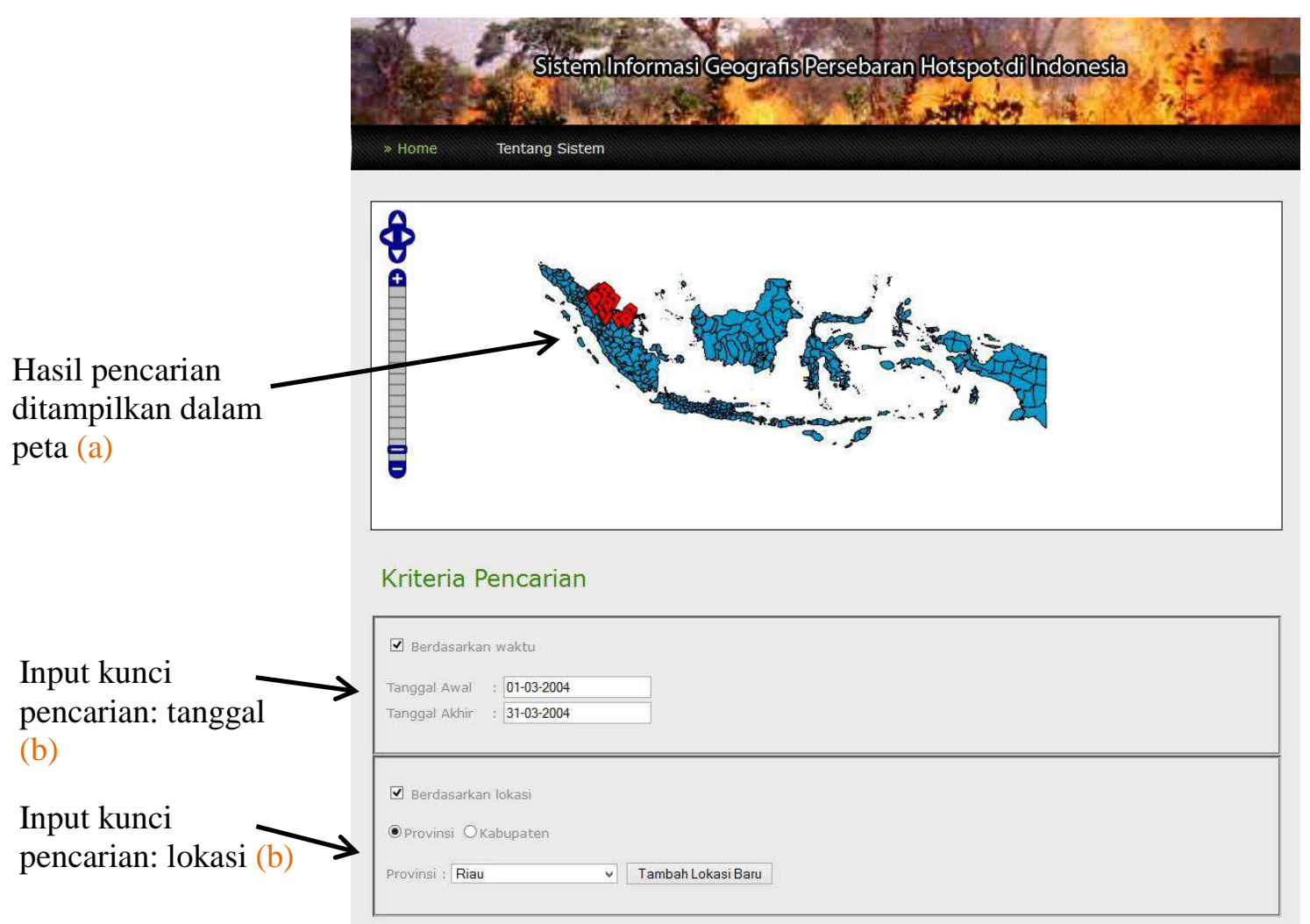

Hasil pencarian dalam bentuk tabel (c)

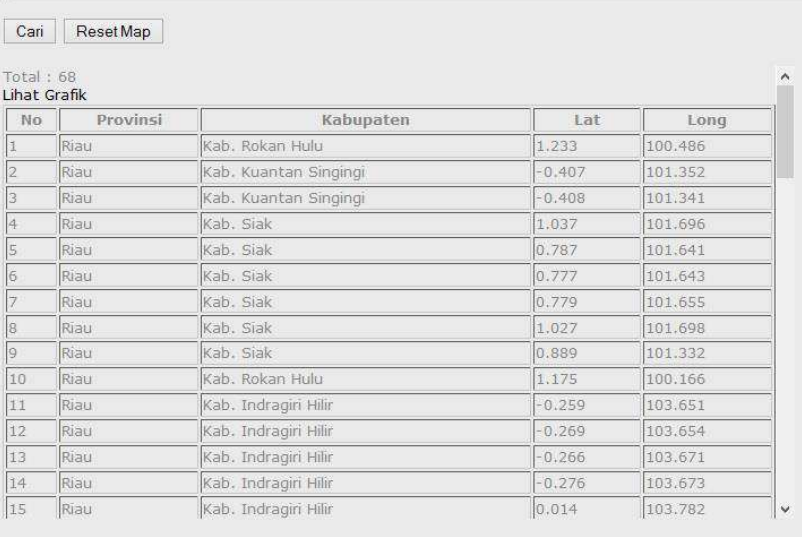

Gambar 5 Antarmuka modul pencarian berdasarkan waktu

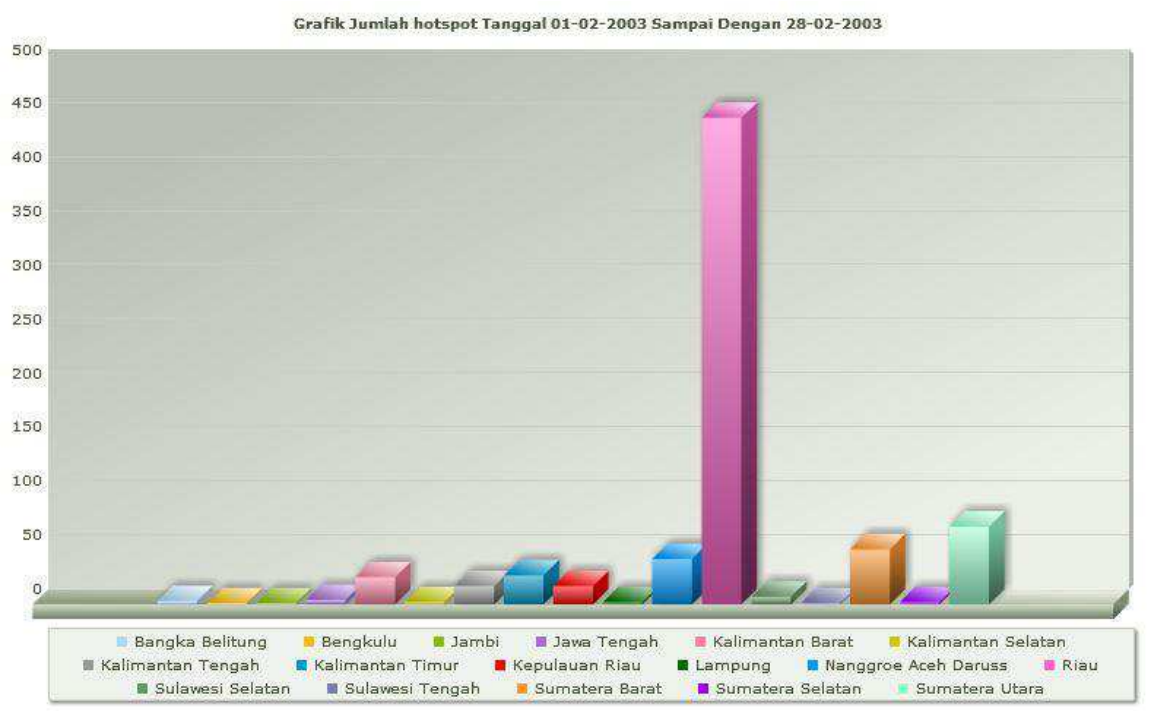

Gambar 6 Grafik hasil pencarian titik api berdasarkan waktu 
Pencarian titik api dapat dilakukan berdasarkan lokasi maupun waktu dan lokasi. Berdasarkan lokasi, informasi titik api yang ditampilkan berdasarkan daerah yang dipilih, penyajian informasi pada grafik memberikan informasi jumlah hotspot per tahun berdasarkan kabupaten yang dipilih, dan grafik yang digunakan bertipe garis. Berdasarkan waktu dan lokasi, ada 2 kriteria pilihan yaitu pencarian berdasarkan provinsi atau kabupaten dalam rentang waktu tertentu. Untuk berdasarkan provinsi, informasi titik api yang ditampilkan berdasarkan provinsi dalam rentang waktu tertentu dan penyajian informasi grafik memberikan informasi jumlah titik api berdasarkan rentang waktu dan provinsi yang dipilih. Untuk berdasarkan kabupaten, informasi titik api yang ditampilkan berdasarkan kabupaten dalam rentang waktu tertentu dan penyajian informasi grafik memberikan informasi jumlah titik api berdasarkan rentang waktu dan kabupaten yang dipilih.

\section{Pengujian}

Pengujian SIG telah dilaksanakan menggunakan metode black box dengan skenario uji yang meliputi pengujian fungsionalitas utama dari sistem. Tujuannya untuk mengetahui apakah fungsi-fungsi yang terdapat pada sistem berjalan sesuai dengan yang diharapkan. Fungsi-fungsi yang diuji meliputi: fungsi menampilkan peta Indonesia, fungsi pan map (fungsi untuk menggeser peta sesuai dengan keinginan), fungsi zoom in, fungsi zoom out, fungsi pencarian. Skenario uji dan hasil uji fungsionalitas sistem dapat dilihat pada Tabel 3. Berdasarkan hasil pengujian dapat dinyatakan bahwa SIG berbasis web yang dibangun telah dapat memberikan informasi berupa ringkasan data histori hotspot dalam pencegahan kebakaran hutan.

Tabel 3 Hasil pengujian SIG menggunakan metode Black-Box

\begin{tabular}{|c|c|c|c|}
\hline Pengujian & Skenario & Hasil yang diharapkan & Hasil Uji \\
\hline $\begin{array}{l}\text { Menampilkan peta } \\
\text { Indonesia }\end{array}$ & $\begin{array}{l}\text { Awal mengakses web, peta } \\
\text { Indonesia ditampilkan }\end{array}$ & Gambar peta ditampilkan & Sukses \\
\hline $\begin{array}{l}\text { Menyediakan } \\
\text { fungsi pan map }\end{array}$ & $\begin{array}{l}\text { Klik kanan pada peta lalu geser } \\
\text { peta sesuai dengan keinginan }\end{array}$ & Peta bergeser & Sukses \\
\hline $\begin{array}{l}\text { Menyediakan } \\
\text { fungsi zoom in dan } \\
\text { Zoom out peta }\end{array}$ & $\begin{array}{l}\text { Mengakses simbol } \\
\text { zoom-in dan zoom-out } \\
\text { pada peta }\end{array}$ & $\begin{array}{l}\text { Ukuran peta menjadi lebih besar } \\
\text { atau kecil }\end{array}$ & Sukses \\
\hline \multirow[t]{2}{*}{$\begin{array}{l}\text { Menampilkan hasil } \\
\text { pencarian titik api } \\
\text { berdasarkan lokasi } \\
\text { dan waktu }\end{array}$} & $\begin{array}{l}\text { 1. Waktu } \\
\text { Ceklist checkbox berdasarkan } \\
\text { waktu lalu pilih tanggal yang } \\
\text { diinginkan }\end{array}$ & $\begin{array}{l}\text { Menampilkan pemetaan hotspot } \\
\text { ke peta berdasarkan waktu, } \\
\text { menampilkan hasil pencarian } \\
\text { dalam bentuk tabel dan grafik. }\end{array}$ & Sukses \\
\hline & $\begin{array}{l}\text { 2. Lokasi } \\
\text { Ceklist checkbox berdasarkan } \\
\text { lokasi lalu pilih lokasi yang } \\
\text { diinginkan } \\
\text { 3. Waktu dan lokasi } \\
\text { Ceklist checkbox berdasarkan } \\
\text { waktu dan lokasi (provinsi atau } \\
\text { kabupaten) lalu pilih tanggal dan } \\
\text { lokasi (provinsi atau kabupaten) } \\
\text { yang diinginkan }\end{array}$ & $\begin{array}{l}\text { Menampilkan pemetaan hotspot } \\
\text { ke peta berdasarkan lokasi, } \\
\text { menampilkan hasil pencarian } \\
\text { dalam bentuk tabel dan grafik. } \\
\text { Menampilkan pemetaan hotspot } \\
\text { ke peta berdasarkan lokasi } \\
\text { (provinsi atau kabupaten) dalam } \\
\text { waktu rentang tertentu, } \\
\text { menampilkan hasil pencarian } \\
\text { dalam bentuk tabel dan grafik. }\end{array}$ & Sukses \\
\hline
\end{tabular}

\section{SIMPULAN}

OpenGeo Suite dapat mempermudah pembuatan sistem informasi geografis (SIG) berbasis web untuk manajemen data histori hotspot, karena aplikasi ini menggabungkan PostgreSQL dengan Geoserver tanpa harus mengetahui rincian teknisnya. SIG berbasis web yang telah dibangun memiliki fitur-fitur utama dalam pengelola data histori hotspot yaitu 
menampilkan peta, fungsi pan map, zoom in, zoom out dan fungsi pencarian persebaran histori hotspot. Berdasarkan hasil pengujian terhadap sistem dapat dinyatakan bahwa SIG yang dibangun telah dapat memberikan informasi berupa ringkasan data histori hotspot yang dapat membantu dalam pengambilan keputusan terkait pencegahan kebakaran hutan.

\section{DAFTAR PUSTAKA}

Chang KT. 2002. Introduction to Geographic Information Systems. New York (US): The McGraw-Hill Companies, Inc.

Dong X, Shao G, Limin D, Zhanqing H, Lei T, Hui W. 2006. Mapping forest fire risk zones with spatial data and principal component analysis. Science in China: Series E Technological Sciences 49:140-149

Hai-wei Y, Fan-hua K, Xiu-zhen L. 2004. RS and GIS-based forest fire risk zone mapping in Da Hinggan Mountains. Chinese Geographical Science 14(3):251-257.

Mulyanto D, Masamu A, Satoshi T. 2001. Forest fire hazard model using remote sensing and geographic information systems: toward understanding of land and forest degradation on lowland areas of East Kalimantan Indonesia. Di dalam: Proceedings of the $22^{\text {nd }}$ Asian Conference on Remote Sensing; Singapore, 2001 Nov 5-9.

OpenGeo. 2012. Introduction to The OpenGeo Suite. [Internet]. [diunduh 2013 jul 10].Tersedia pada http://presentations.opengeo.org/2012_FOSSGIS/suiteintro.pdf.

Pressman RS. 2005. Software Engineering: A Practitioner's Approach Ed ke-6. Boston (US): McGraw Hill.

Razali SM, Nuruddin AA, Malik IA, Fatah NA. 2010. Forest fire hazard rating assessment in peat swamp forest using Landsat thematic mapper image. J. Appl. Remote Sens. 4

Setiawan I, Mahmud AR, Mansor S, Sharriff MAR, Nuruddin AA. 2004. GIS-grid-based and multi-criteria analysis for identifying and mapping peat swamp forest fire hazard in Pahang, Malaysia. Disaster Prevention and Management Journal. 13(5):379-386.

Sugiharyanto. 2007. Geografi dan Sosiologi. Firmasyah F, Sanud, Bidya, Sulistiyanto D, editor. Jakarta (ID): Yudhistira. 